\title{
UNCLASSIFIED
}

HW-17822

Chanlatry

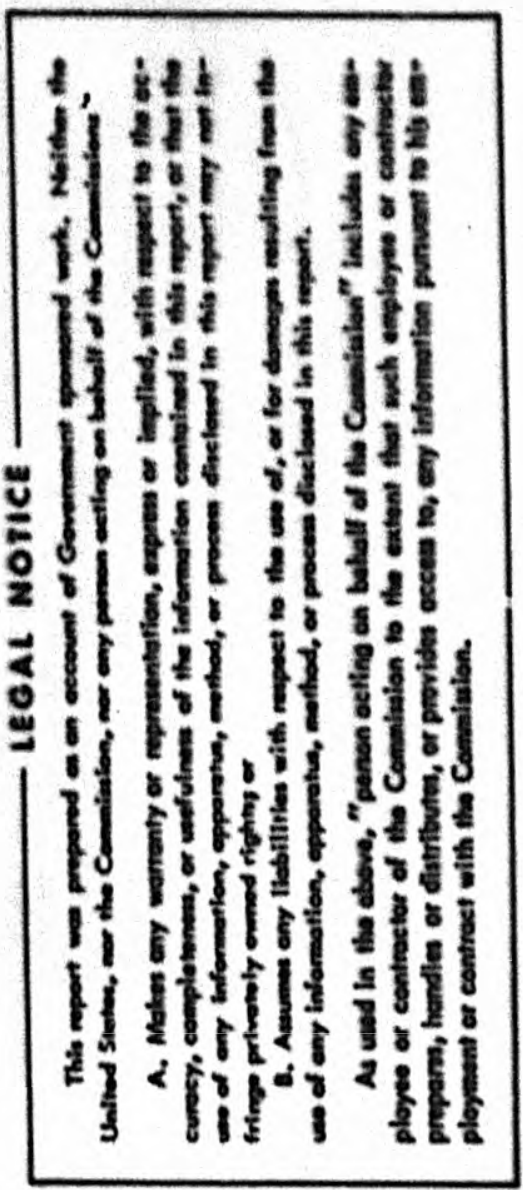

UNITED STATES ATOMIC ENEROY COMMISSION

REFRACTIVE INDEX MEASUREMENT8

By

L. L. Burger

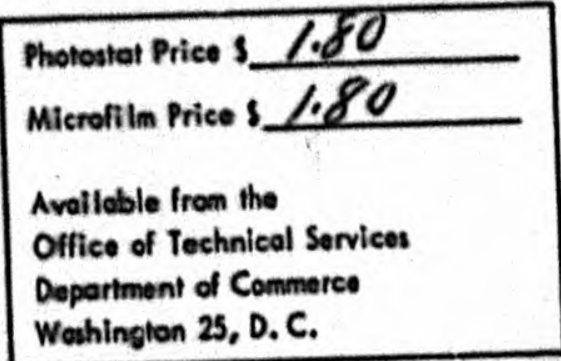

May 17, 1950

Hanford Works

Richland, Wash.

Technical Information Service Extension, Oak Ridge, Tenn. 
May 27. 1950

To: r. W. Albaugh

Froa: I. II Burger

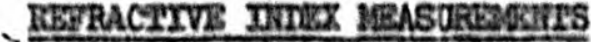

Current physical atudsea or Redox Bolutioas and currept metal vasto solutions heve included a nuaber of refractomotric inveatigntions. Aelab erva la. Sormation pertinent to the structural nature of solutions these date have revealed that the rerractions of a number of congtituento in process otrenane are eufficlently different from those of the solvonts that analytical application

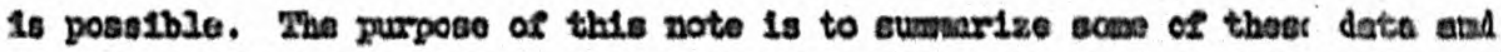
to point out a fev 2instations of the mattod. , s 7 .

Refractonetric wothods for analysis and control, in organic ohoniotsy are well known. Lack of extensive use in analysis of lnorgante bolutions hate resulted probably fron the leck of apeciflost to sor Indsividual lous and to tho Sact that othor methode vore avaljol le.

In Table I are 11atod the indices of refrietion at abu sor a zamber of puzo compounds. 


\section{$\because$ UR:LASEL:IED

\section{taber $x$}

$\frac{\text { Aubatenea }}{\pi_{20}}$

Bloxone

$\mathrm{EIO}_{3}$ n.

1.3325

1. Leas

1.4976

2.3938

$1.397^{15.4^{\circ} \mathrm{C}}$

Although milecular refrection is a vave truly sedstive rmetion, it has been cononstroted both exporianta3y and theoretically that for dilute solutions the Index of refrection is a Iinear sunction of conecntration. In fect, if weight per und: voiten is the concentration unit the linearity halde for concentrated solutioas.

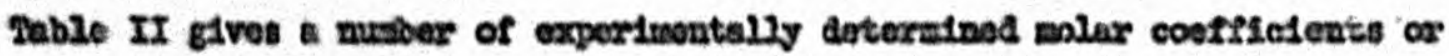
$\triangle \mathrm{n}_{\mathrm{D}}^{2 \mathrm{~S} / \text { mole solute }}$

\begin{tabular}{|c|c|c|}
\hline Balvent & Solute & $\Delta \mathrm{g}^{25} / \mathrm{mo10}$ \\
\hline $\mathbb{Z}_{2} \mathrm{O}$ & $\mathrm{OO}_{2}\left(\mathrm{NOO}_{3}\right)_{2}$ & 0.0352 \\
\hline $\mathrm{Z}_{2} \mathrm{O}$ & $\mathrm{Al}\left(\mathrm{mO}_{3}\right)_{3}$ & 0.0347 \\
\hline $\mathrm{B}_{2} \mathrm{O}$ & $\mathrm{EHO}_{3}$ & 0.0069 \\
\hline $\mathrm{B}_{2} \mathrm{O}$ & $\mathrm{FallO}_{3}$ & 0.010 \\
\hline Bexone & $\mathrm{EO}_{2}\left(\mathrm{mO}_{3}\right)_{2}$ & 0,028 \\
\hline Bexone & $\mathrm{HMO}_{3}$ & $0.000-0.002$ \\
\hline 25\% TBP In Vareol & $\mathrm{DO}_{2}\left(\mathrm{NOO}_{3}\right)_{2}$ & 0.020 \\
\hline $25 \%$ TaP in Vareol & $\mathrm{ExO}_{3}$ & -0.002 \\
\hline
\end{tabular}




\section{UNCLASSIF IED}

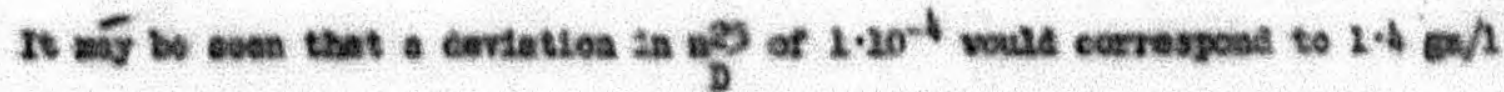

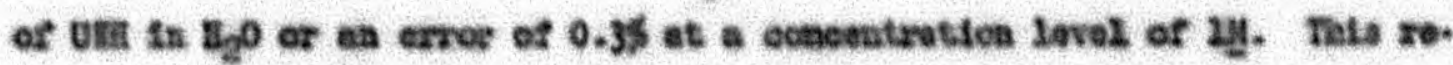

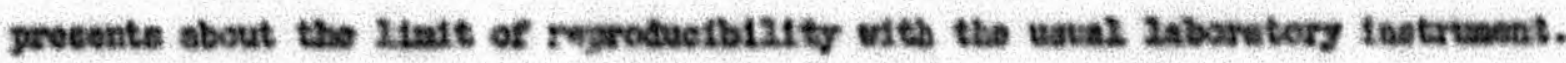

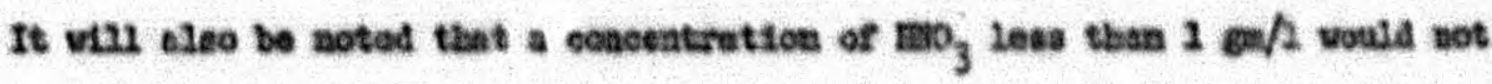

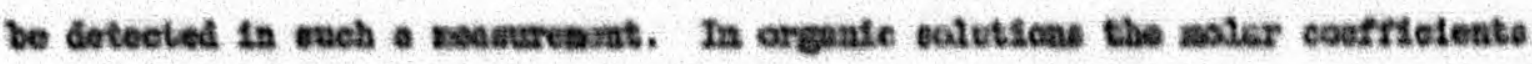
are ozaller. A atutlar retrection Index error in a Fap - Varaol ooletion vould correapond to $2.4 \mathrm{gas} / \mathrm{A}$ urs. The valuos in Tobles I and II are tentative and uneertasn In the Last IIgurs and are efven for coesertsen purposec only.

Some ccansent regarding tochalgue of nearureant vould bo in order. Tho ordinary abbé can be resd vith an uneertasnty of $\$ 1 \cdot 10^{-4}$. The P seleleu abbé 1a accurate to $12 \cdot 20^{-5}$, the Aippins refrectonster to 3 or $4 \cdot 10^{-5}$. Otber instraments ouch es the spoctronoter and the Pulfrich refracteseter are in general alower to opereto, and therefor not as desizable for routine use. The inter. ferometer vill extend the mearuresent to $<1 \cdot 10^{-6}$, and oxee the apparntus 1 set up se ouremente can be made rapidly. Tenperature control required doponde on the solvent and the precision deeired. For aqueous solutions to $\pm 1 \cdot 20^{-4}, \sim \pm 11^{\circ} \mathrm{C}$ Is adequate and cosrespondingly greater control is regulrod for bigher procialon. Teaperature coefelcients gor argunle colvents axe roughly 4 times as Large, and greater control 16 roguired. With the Interferonetor tenperature arfects are Iargoly cancellod. Evaporetion of tho ealvent during a raeasurement is a coince of errer but olnce onls a fov ceconds are required for the opticel adjustment the exror cen be modo insienificant in the solutions under asseuesion.

With sowe of the Instrunents modiflcationo vould be neceosary for continuous use with corrosive colutions. The depirability of handing radioactive solutione 16 open to question. However it way be pointed out that the guantit1es of volution can bo small, $\sim 2 \zeta \lambda$. The possibility of application of photographle or photoelostrele recording to an Instzrusent such as the dipping rerrectometer cannot be rwloc. out.

\section{UNCLASSIFIEID}




\section{UWCLASSIFIED andreae}

Tas zeptaits eal efmalatty of refractive Index noneuresents tegether vith the anall anount of Lquid rogutred auggost surther inveatigation of the nethod In andyele of $\mathrm{VO}_{2}\left(\mathrm{HO}_{3}\right)_{2}, \mathrm{As}\left(\mathrm{HO}_{3}\right)_{3}$, and $\mathrm{HiO}_{3}$ ealutions. Sugested applicetions are: (2) analysis of aclutious of 2 compoaente, (2) solutilose of 3 or aore ocmponento Where Indegendent analgtical anthods are avallabse for other oonntituents, (3) deterntnation of the change in concentration of one opectee or (4) monitaring of concentration of varlous procees stroome irroepective of ebsoluto concentaration of Inaivianal eonitituents.

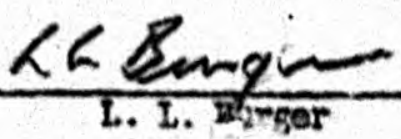

